\title{
Diurnal pattern of rainfall in Cambodia: its regional characteristics and local circulation

\author{
Kumiko Tsujimoto ${ }^{1 *}$ (D) Tetsu Ohta ${ }^{2}$, Kentaro Aida ${ }^{3}$, Katsunori Tamakawa ${ }^{4}$ and Monichoth So Im $^{5}$
}

\begin{abstract}
We analyze the hourly rainfall data of 30 rain gauges in Cambodia from 2010 to 2015 to focus on the diurnal pattern of rainfall and its regional characteristics, with the underlying mechanisms inferred from the observed data. The observed annual rainfall in inland Cambodia ranges from 1087 to $1528 \mathrm{~mm}$ on station-average. Approximately $5-20 \%$ of the annual rainfall occurs during the pre-monsoon season, $50-78 \%$ during the summer monsoon season, and $12-36 \%$ during the post-monsoon season. During the pre-monsoon season, rainfall is dominant on the coast and over the Cardamom Mountains, with a maximum in the afternoon. The rainfall amount is smaller around the Tonle Sap Lake. During the summer monsoon season, rainfall is larger in the northern region and smaller in the western region in inland Cambodia, in both amount and proportion to annual rainfall. The rainfall amount on the coast is distinctively large. The diurnal rainfall maximum occurs in the early afternoon in the Cardamom Mountains, in the afternoon on the plain at the southwestern side of the Tonle Sap Lake, in the evening on the wide area of the northeastern side of the lake, and in the early morning on the coast. The clear regional characteristics in the diurnal rainfall pattern suggest significant effects of local features, even during the Asian summer monsoon season. During the post-monsoon season, rainfall is larger on the southwestern side of the Tonle Sap Lake with dominant nocturnal rainfall. These diurnal patterns are, however, not clear on some days, and analysis of the synoptic-scale atmospheric condition suggests the effect of the large-scale low-pressure system and disturbances on the appearance of the clear diurnal rainfall pattern. The effect of land-lake and mountain-valley circulations on forming the diurnal rainfall pattern is also implied from ground-observed meteorological data, although further numerical studies are required to examine the detailed mechanisms. The study of local effects on rainfall with consideration of the landsurface dynamics may aid flood and drought management in Cambodia by facilitating a greater understanding of its rainfall pattern.
\end{abstract}

Keywords: Diurnal pattern of rainfall, Local circulation, Land breeze, Sea/lake breeze, Katabatic wind, Anabatic wind, Asian summer monsoon, Cambodia, Indochina Peninsula, Tonle Sap Lake

\section{Introduction}

\section{Study area}

Cambodia is located in the southern portion of the Indochina Peninsula, in the lower Mekong River basin (Fig. 1). In the center of the country is a huge lake, the Tonle Sap (Fig. 2), which has an area of about $2500 \mathrm{~km}^{2}$ at the end of the dry season (around April-June) and expands to about five times this size at the end of the rainy season (around October-November) in connection with the seasonal rise of the water level of the Mekong River (Masumoto et al. 2007).

\footnotetext{
* Correspondence: tsujimoto@okayama-u.ac.jp

${ }^{1}$ Graduate School of Environmental and Life Science, Okayama University,

3-1-1 Tsushima-naka, Kita-ku, Okayama 700-8530, Japan

Full list of author information is available at the end of the article
}

The seasonally expanding area of the lake is indicated by the white hatched area in Fig. 2. Responding to the change in lake area are the surrounding land-cover characteristics and soil moisture, which also change drastically within a year. Topographically, most of the land to the west of the Mekong River in Cambodia is basin-shaped flat terrain except for the Cardamom Mountains to the southwest facing the Gulf of Thailand, with the highest elevation at $1813 \mathrm{~m}$.

Since it is located on the Indochina Peninsula, Cambodia is influenced by both the Asian summer monsoon (ASM), or Indian monsoon, and the Asian winter monsoon (AWM) (Chang et al. 2005). The ASM is established in early to middle May, associated with strong convection and the change of direction of the 


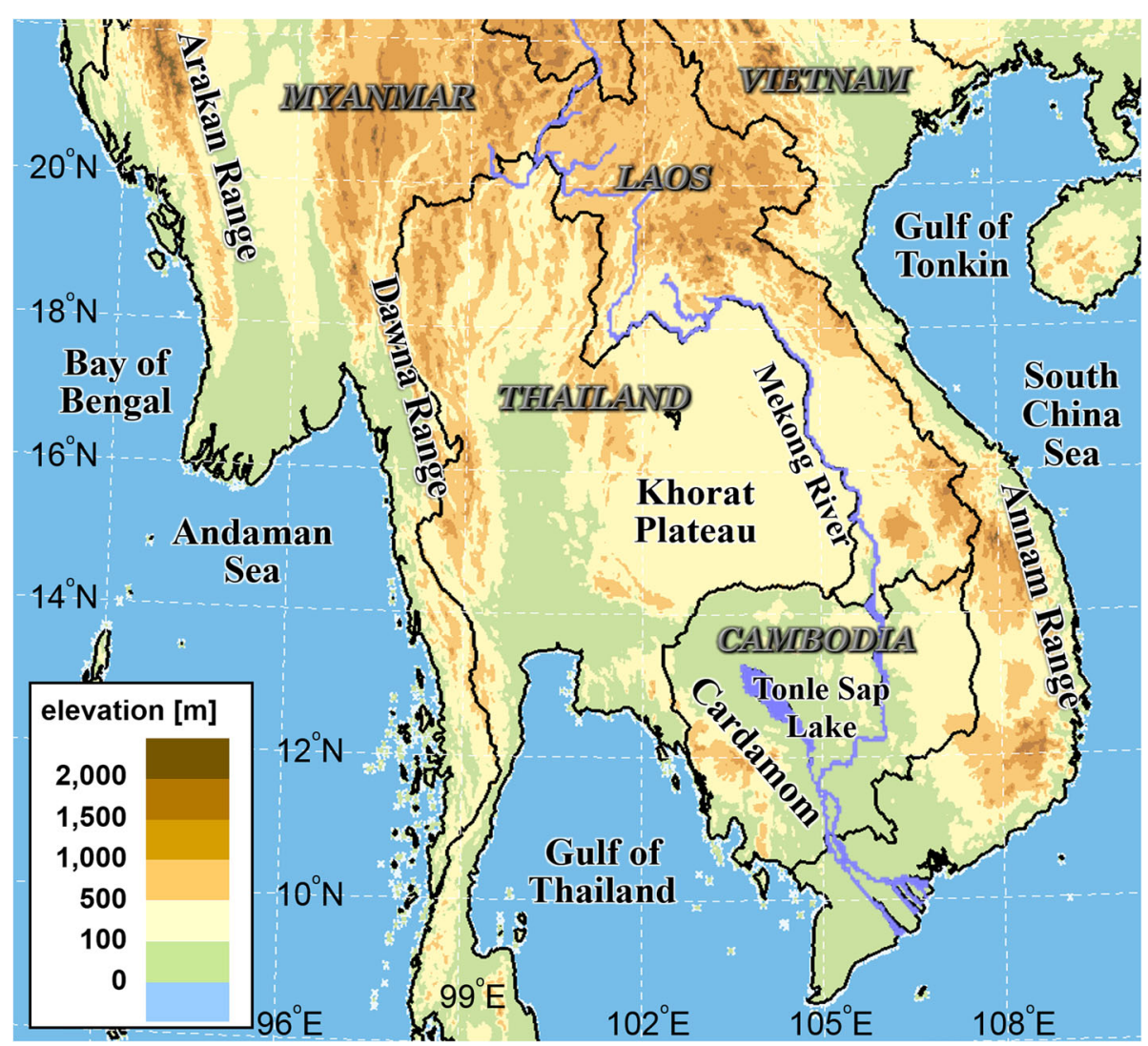

Fig. 1 Topography of the Indochina Peninsula and the location of Cambodia. The topographical map is drawn based on the Global 30 Arc-Second Elevation (GTOPO30) data provided by the US Geological Survey

prevailing wind over the Bay of Bengal, the Indochina Peninsula, and the South China Sea (Zhang et al. 2002). In the boreal winter season, the entire Indochina is subject to the dry season from mid-December until mid-April (Yen et al. 2011).

\section{Rainfall characteristics in the Southeast Asian monsoon region}

The onset and withdrawal dates of the rainy season and their spatial distribution over and around the Indochina Peninsula were analyzed by Matsumoto (1997) using rain-gauge data in 1975-1987. He found that the rainy season starts earlier in the inland region of Thailand from late April to early May and withdraws later in the central-eastern coast of Vietnam in late November. Based on his results, the onset date over the southern Indochina Peninsula (around Cambodia) is around 28 April to 8 May, and the withdrawal date is around 31 October to 10 November.

Takahashi et al. (2010a) analyzed summer (MaySeptember) rainfall over the Indochina Peninsula using both satellite and ground observations and found the lowest rainfall over ridges and the leeward side of the high mountains of the Arakan, Dawna, and Annam Ranges and the highest rainfall offshore in the eastern Bay of Bengal, in the eastern Gulf of Thailand, and at the windward side of the Annam Range of the eastern Khorat Plateau.

The spatial variability of rainfall has been especially observed in the diurnal precipitation cycles of different regions. Hirose and Nakamura (2005) examined the spatial and diurnal variations of rainfall over Asia using satellite data, considering precipitation at multiple scales, to find small precipitation systems occurring most frequently around the early afternoon over most land areas, and large systems associated with the terrain occurring mostly in the evening.

The diurnal cycle of convection tends to be stronger over land during summer, with maxima in the late afternoon or early evening under a dominant influence of daytime boundary-layer heating (Chaboureau et al. 2004). Tsujimoto et al. (2008) analyzed the diurnal cycle of rainfall in Cambodia and showed clear afternoon rainfall peaks at two stations in Cambodia, in the city of Phnom Penh and over a paddy field near Phnom Penh, and a weaker afternoon peak over the Tonle Sap Lake near the city of Siem Reap (see Fig. 2). As Wallace (1975) has summarized, daytime rainfall peaks are 


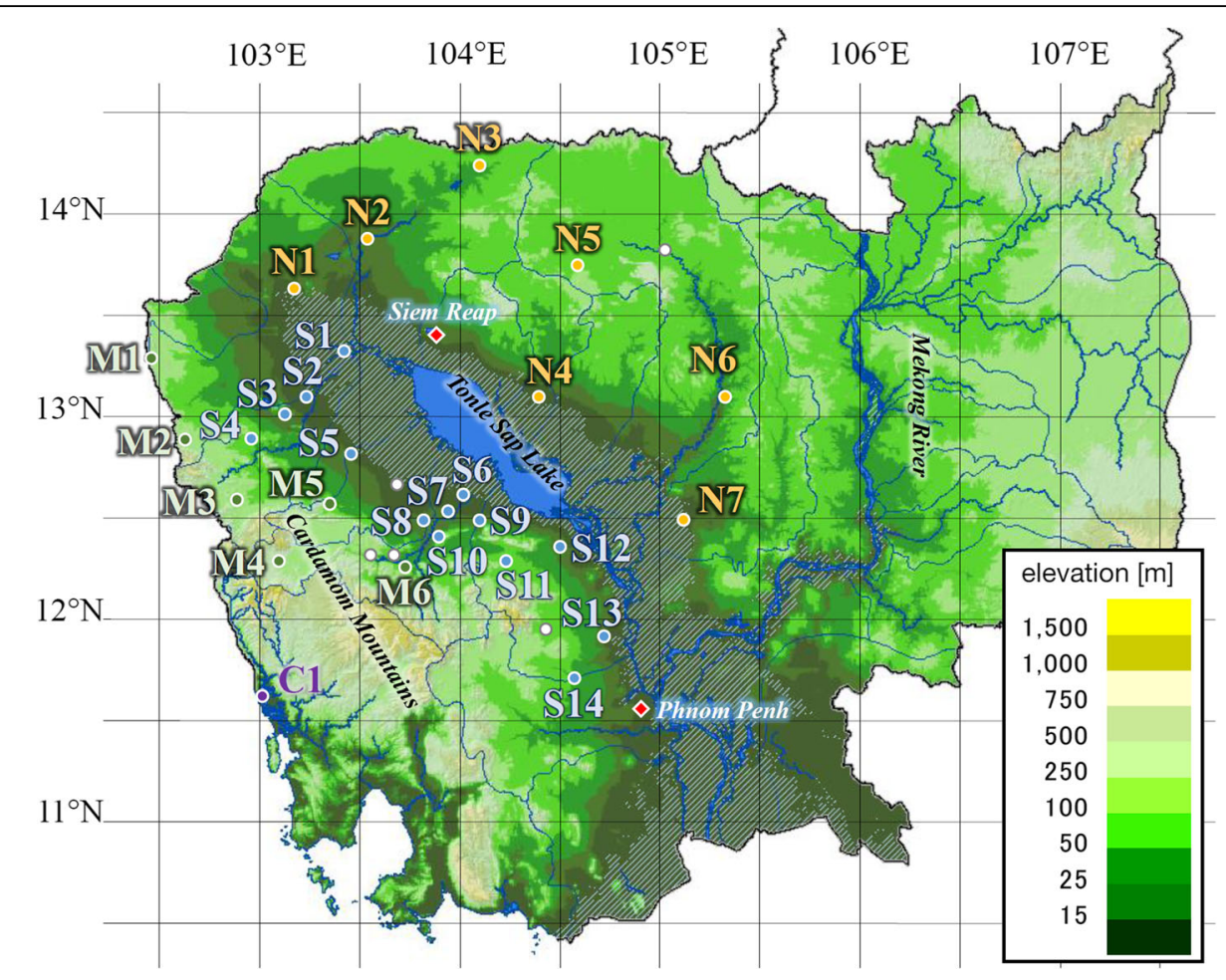

Fig. 2 Map of Cambodia and location of rain gauges with their symbols (N1-N7 in yellow for northern stations, S1-S14 in blue for southern stations, M1-M6 in green for mountainous stations, and C1 in purple for the coastal station). Four white circles show the excluded stations for the analysis due to frequent missing data. Station S7 is equipped with an AWS. The color shades indicate the elevation, and the white hatched area around the Tonle Sap Lake is its seasonal expansion area where it is under water from the middle of the rainy season (around August) to the beginning of the dry season (around December). The base map is adapted from The Atlas of Cambodia (Save Cambodia's Wildlife 2006)

mainly controlled by thermodynamic processes affecting the atmospheric stability. Sensible heat released from the ground surface under daytime solar radiation warms the lower boundary layer, which decreases the low-level atmospheric stability, leaving favorable conditions for moist convection during the afternoon and thus contributing to the afternoon maxima of rainfall observed at many places over land.

However, the rainfall peak tends to occur at night or in the early morning over some regions. For example, over the southern and central Tibetan Plateau, afternoon rainfall is pronounced over mountains, while late evening to early morning rainfall is dominant over valleys and lakes (Fujinami et al. 2005; Singh and Nakamura 2009). Over the southward slope of the Himalayas, late evening to early morning rainfall is more pronounced (Bhatt and Nakamura 2005). Over tropical Asia in Bangladesh, Thailand, Vietnam, and Malaysia, Ohsawa et al. (2001) analyzed the spatial distribution of summer rainfall (June-August) from rain gauges as well as the convective activity observed by satellites and found that late night-early morning rainfall was stronger in intensity.

Based on the summary by Wallace (1975), apart from the abovementioned thermodynamic processes, dynamical processes may also explain the shift of rainfall maxima to other hours of the day, such as the convergence of flow within the planetary boundary layer. In addition, radiative cooling from cloud tops and low-level warm advection are thermodynamic processes that enhance nighttime rainfall maxima (Wallace 1975). Moreover, the downward propagation of atmospheric convective systems associated with rainfall peaks along mountain slopes has been reported at various places. Using rain gauges in China, Yu et al. (2007) showed the eastward propagation of the diurnal phase of rainfall systems along the Yangtze River Valley in summer, with midnight maxima in the upper valley, early morning maxima in the middle valley, and late afternoon maxima in the lower valley. Satomura (2000) numerically simulated the eastward propagation of rainfall initiated at the leeward side of the Dawna Range in western Indochina in the late afternoon with water vapor supplied from the Andaman Sea. As a result, there was a nighttime maximum of precipitation in the inland areas of northeast Thailand. Okumura et al. (2003) analyzed the diurnal cycle of precipitation in rainy seasons using radar echo data observed in northern Thailand to show moving mesoscale systems with a phase delay corresponding to the distance from mountains. Satomura et al. (2011) used the radar echo area observed in Lao PDR and analyzed the propagation 
speed of its diurnal variation in relation to the large-scale wind in the lower troposphere. Takahashi et al. (2010a) examined the $3 \mathrm{~h}$ mean diurnal cycle of 10-year climatological rainfall occurring from May to September to show that, around the Tonle Sap Lake in Cambodia, evening rainfall begins at approximately 16:00-19:00 Local Time (LT) and becomes strongest at 19:00-22:00 LT, before weakening in the middle of the night.

As Takahashi et al. (2010a) have pointed out, the observed diurnal cycle of rainfall is a "visualized" result of the interaction of several mechanisms under both large- and local-scale effects. Thus, the observation and interpretation of regional rainfall characteristics in terms of the diurnal cycle and the spatial variability are useful for understanding the local circulation, especially in regions where the observational network is sparse.

\section{Limitations and importance of studying rainfall in Cambodia}

Although many studies exist on the climatology and rainfall in the Indochina Peninsula (Nieuwolt 1981; Matsumoto 1997; Satomura 2000; Ohsawa et al. 2001; Okumura et al. 2003; Xie et al. 2006; Tsujimoto et al. 2008; Takahashi et al. 2010a; Satomura et al. 2011; Takahashi 2013; Takahashi 2016), limitations of the automatic rain-gauge network in Cambodia have led preceding studies of rainfall in Indochina to use rain-gauge data from mostly only neighboring countries and/or satellite data. As mentioned by Takahashi et al. (2010a), rain-gauge observations were inadequate for analyzing the diurnal cycle of rainfall over the Indochina Peninsula because of their limited availability, whereby gauges have only been located in populated and low-altitude areas until very recently. Even regarding floods and droughts, which frequently affect Cambodia and result in enormous damage (Torti 2012; National Committee for Disaster Management and United Nations Development Programme 2014; Chhinh and Millington 2015), such events are usually classified in terms of the inundated area, the water level of rivers and lakes, and damage to households, people, and agricultural production. Hence, the spatio-temporal distribution of rainfall itself over Cambodia has yet to be clarified in detail. Even though the inundation area of the Tonle Sap Lake is highly affected by the water level of the Mekong River due to its hydrological system described above, and thus, the rainfall amount in the upper Mekong River basin and the water level of the Mekong can explain the floods and droughts in Cambodia to a large extent, deepening the understanding of rainfall that directly falls onto Cambodia, including both large-scale and locally induced rainfall, will help the development of strategies for mitigating water-related disasters such as floods and droughts.

In addition, while surface properties such as vegetation and soil moisture are considered important for the formation and distribution of rainfall (Xie et al. 2006), these effects are not yet well understood. Takahashi et al. (2010b) examined the potential impact of land-surface conditions on regional climate over the Indochina Peninsula associated with the diurnal precipitation cycle using a high-resolution regional climate model. Such a numerical study was also conducted for Bangladesh, a wet tropical region, to examine the precipitation sensitivity to soil moisture in different seasons (Sugimoto and Takahashi 2017). The relationship between soil moisture and precipitation in Bangladesh was recognized by satellite observation as well, with higher afternoon precipitation intensity over drier land surfaces over a flat terrain (Ono and Takahashi 2016).

With the unique hydrological characteristics of land in Cambodia, the rainfall pattern would be highly affected by surface heterogeneity, in both time and space, resulting in rainfall characteristics within Cambodia having regional characteristics. Clear land-lake circulation, with a daytime lake breeze (onshore flow) and nighttime land breeze (offshore flow) in the presence of a linear convective system at its front, has been recognized in Cambodia by both the analysis of observations and numerical simulations (Tsujimoto and Koike 2008 Tsujimoto and Koike 2013). Although the effect of mountain-valley circulation interacting with land-lake circulation is often discussed in studies on the diurnal cycle of rainfall around the lake (e.g., Verburg and Antenucci 2010; McGloin et al. 2014), the surrounding area of the Tonle Sap Lake is almost flat (Fig. 2) compared with other lakes in the world; therefore, the effect of land-lake circulation would clearly appear, even though the effects of mountains also exist. Tsujimoto and Koike (2012) analyzed rain-gauge data in Cambodia together with global reanalysis data and found that about $30-40 \%$ of post-monsoon rainfall was induced by the local circulation within Cambodia.

However, because of the lack of multi-year hourly rainfall data at various places in Cambodia, rainfall distribution associated with local-scale heterogeneity of the land, as well as the diurnal, seasonal, and intra-seasonal variations, has not been explored. To rectify this situation, we installed 16 automatic rain gauges in September 2009 and rehabilitated a further 19 abandoned rain gauges for establishment of the ground truth of rainfall distribution in Cambodia. We concentrate on the surrounding area of the Tonle Sap Lake west of the Mekong River, with the aim of detecting the influence of the Tonle Sap Lake.

\section{Scope of this study}

In this study, we aim to quantify the rainfall amount in Cambodia, i.e., the annual and seasonal amounts at various places from 2010 to 2015 . We also aim to 
clarify the diurnal rainfall pattern and its regional characteristics for the pre-monsoon, summer monsoon, and post-monsoon seasons to highlight locally induced rainfall. The intra-seasonal variability of the clarity of the diurnal rainfall cycle is discussed as well to examine the influence of synoptic-scale phenomena on locally induced rainfall. Quality-controlled hourly rainfall data from 30 rain gauges are used to quantify the diurnal patterns of rainfall over Cambodia. We also refer to data from a ground meteorological observation station to examine the possible mechanisms underlying the observed diurnal patterns of rainfall in each region in each season.

\section{Methods/Experimental}

\section{Rainfall data}

The locations of the automatic rain gauges from which we gather rainfall data in Cambodia are shown in Table 1 and Fig. 2, along with each station's symbol. At station S7 in the city of Pursat, surface meteorological variables are observed in addition to rainfall by an Automatic Weather Station (AWS), which is explained in the next subsection.

Rain-gauge locations were carefully selected to be away from tall trees and buildings to carry out observation at open and wide spaces and to be safe against theft and interference by humans, animals, vehicles, and so on. At locations where shrubs were growing, we asked local residents and/or landowners to keep them cut during the observation period. The setting environment is different among stations, as summarized in Table 1 . Some stations are inside the observation sites of the local meteorological office or grounds of the local district/commune/police office, and others are inside gardens of private houses or paddy fields. The gauge at station S1 was installed on a roof over a private house, since the ground there is completely inundated as a part of the lake during the rainy season. The height of the rain-gauge orifice to the land or water surface there is around 4-8 $\mathrm{m}$ and changes within a year, following the seasonal change of the water level of the lake.

Each rain gauge was equipped with a tipping bucket and a data logger. There are three types of gauges (A, B, and $\mathrm{C}$ as indicated in Table 1) with different specifications. The type-A rain gauge is a No. 34-T (RA-1) gauge manufactured by Ota Keiki Seisakusho Co., Ltd., and data are recorded to the Onset Computer Corporation's HOBO event data logger (H07-002-04). It measures at a $0.5 \mathrm{~mm}$ resolution with a receiving orifice diameter of $200 \mathrm{~mm}$. All the type-A rain gauges had been abandoned for observation as of June 2009, and therefore, we rehabilitated these rain gauges to restart observation where possible. On restarting the observation, we checked the performance of tipping buckets and data loggers by pouring known amounts of water; we also carefully cleaned the buckets, nets, and data loggers and changed the desiccants and batteries to new ones. The type-B rain gauge consists of an RG3-M gauge and a $\mathrm{HOBO}$ pendant event data logger (UA-003-64) produced by the Onset Computer Corporation. Its measuring resolution is $0.2 \mathrm{~mm}$, and the receiving orifice diameter is $154 \mathrm{~mm}$. All the type- $B$ rain gauges were installed by the authors in September 2009, especially concentrating on the poorly gauged area in the northeastern side of the lake. At two stations ( $\mathrm{S} 4$ and $\mathrm{M} 3$ ), the type-B rain gauges were installed next to the type-A gauges to check the instrumental difference on the observed rainfall amount. The type- $\mathrm{C}$ gauge is an A-TK-2 rain gauge manufactured by Takeda Keiki Kogyo Co., Ltd., constituting one component of the AWS that was also installed by the authors. It has a gauge resolution of $1.0 \mathrm{~mm}$ with a receiving orifice diameter of $200 \mathrm{~mm}$. Rainfall data were recorded, along with other meteorological variables, to a Campbell Scientific, Inc. data logger (CR1000). After the rehabilitation and installation of rain gauges in September 2009 , we serviced stations two to three times per year to obtain continuous, highly reliable, and quality-controlled data for our detailed investigation of the rainfall in Cambodia.

The quality control of data was applied in two stages. First, we inspected the physical status of each station at every visit and carefully cleaned the gauges and removed any tall grass surrounding the station. Any rainfall counts recorded by mistake during maintenance work were removed. For data loggers found to function abnormally, or where there existed some artificial disturbance to the observation (i.e., construction work, interference by humans or animals, or excess dust, insects, or leaves affecting the gauge or tipping bucket), we assumed that observations from that station from the previous to the current data collection dates are missing. Second, in graphs of the rainfall distribution in which exceptionally high or low data occurred, we assumed that observations around that period are also missing. While this standard is not quantitative, the reference to local information allows us to treat doubtful data as missing.

Following the removal of questionable data, we converted the recorded data to hourly and daily datasets. For definitions of date and hour, we used Cambodian LT (UTC $+7 \mathrm{~h})$. We defined hourly rainfall at hour $h$ as accumulated rainfall amount observed from $h: 00: 00$ to $h: 59: 59$. Note that this definition is different from that for the normal gauge observation ( $h-1: 00: 01$ to $h: 00: 00)$, and here we set the definition to match that of the satellite precipitation product, such as Global Satellite Mapping of Precipitation (GSMaP) (Earth Observation Research Center of Japan Aerospace Exploration Agency 2017). 
Table 1 Specification of each station and its gauge used in the analysis

\begin{tabular}{|c|c|c|c|c|c|c|c|c|}
\hline Symbol & Location name & Province & Latitude [ $\left.{ }^{\circ} \mathrm{N}\right]$ & Longitude [ $\left.{ }^{\circ} \mathrm{E}\right]$ & Altitude $[\mathrm{m}]$ & $\begin{array}{l}\text { Setting } \\
\text { environment }\end{array}$ & Gauge type & $\begin{array}{l}\text { Gauge } \\
\text { height [m] }\end{array}$ \\
\hline N1 & Preah Net Preah & Banteay Meancheay & 13.63 & 103.19 & 18 & 2 & B & 0.50 \\
\hline N2 & Chrouy Neang Nuong & Siem Reap & 13.86 & 103.52 & 26 & 2 & B & 0.50 \\
\hline N3 & Anlung Veng & Oddar Meancheay & 14.23 & 104.08 & 58 & 2 & $\mathrm{~B}$ & 0.5 \\
\hline N4 & Kampong Kdei & Siem Reap & 13.12 & 104.34 & 21 & 2 & B & 0.50 \\
\hline N5 & Srayang & Preah Vihear & 13.72 & 104.55 & 138 & 2 & B & 0.50 \\
\hline N6 & Mean Rith & Kampong Thom & 13.10 & 105.28 & 41 & 3 & B & 0.50 \\
\hline N7 & Kampong Thmar & Kampong Thom & 12.50 & 105.15 & 15 & 1 & B & 0.50 \\
\hline S1 & Bac Prea & Battambang & 13.31 & 103.40 & 8 & 4 & B & - \\
\hline S2 & Battambang & Battambang & 13.09 & 103.21 & 15 & 1 & B & 0.50 \\
\hline S3 & Phnom Sam Pov & Battambang & 13.02 & 103.11 & 15 & 5 & B & 1.38 \\
\hline S4 & Ratanak Mondol & Battambang & 12.89 & 102.97 & 58 & 2 & $\begin{array}{l}\text { A } \\
B\end{array}$ & $\begin{array}{l}1.5 \\
0.5\end{array}$ \\
\hline S5 & Muang Russey & Battambang & 12.78 & 103.45 & 18 & 2 & A & 1.49 \\
\hline S6 & Kandieng & Pursat & 12.61 & 103.99 & 21 & 3 & A & 1.67 \\
\hline S7 & Pursat & Pursat & 12.54 & 103.91 & 20 & 1 & C & 0.60 \\
\hline S8 & Dambat & Pursat & 12.49 & 103.81 & 24 & 3 & A & 1.58 \\
\hline S9 & Koh Chum & Pursat & 12.50 & 104.05 & 28 & 5 & A & 1.48 \\
\hline S10 & Bactra & Pursat & 12.43 & 103.86 & 57 & 3 & A & 1.46 \\
\hline S11 & Bamnak & Pursat & 12.30 & 104.18 & 69 & 3 & A & 1.50 \\
\hline S12 & Boribo & Kampong Chhnang & 12.39 & 104.48 & 17 & 2 & A & 1.50 \\
\hline S13 & Kampong Tralach & Kampong Chhnang & 11.94 & 104.71 & 21 & 3 & A & 1.50 \\
\hline S14 & Peam & Kampong Chhnang & 11.74 & 104.54 & 48 & 3 & A & 1.50 \\
\hline M1 & Phnom Proek & Battambang & 13.22 & 102.40 & 125 & 2 & A & 1.50 \\
\hline M2 & Pailin & Pailin & 12.87 & 102.56 & 219 & 1 & B & 0.26 \\
\hline M3 & Samlot & Battambang & 12.61 & 102.86 & 116 & 2 & $\begin{array}{l}\text { A } \\
B\end{array}$ & $\begin{array}{l}1.50 \\
0.50\end{array}$ \\
\hline M4 & Veal Veng & Pursat & 12.31 & 103.11 & 237 & 2 & A & 1.49 \\
\hline M5 & Bassac Reservoir & Battambang & 12.57 & 103.34 & 49 & 3 & A & 1.46 \\
\hline M6 & Peam & Pursat & 12.28 & 103.72 & 42 & 3 & A & 1.46 \\
\hline C1 & Koh Kong & Koh Kong & 11.61 & 102.99 & 5 & 1 & B & 0.50 \\
\hline - & Preah Vihear & Preah Vihear & 13.80 & 104.98 & 54 & 1 & B & 0.50 \\
\hline- & Rovieng & Pursat & 12.32 & 103.55 & 63 & 3 & B & 1.53 \\
\hline - & Svay Donkeo & Battambang & 12.67 & 103.64 & 15 & 3 & A & 1.50 \\
\hline- & Taing Louch & Pursat & 12.32 & 103.64 & 42 & 3 & $A$ & 1.55 \\
\hline- & Takab & Kampong Chhnang & 12.02 & 104.45 & 64 & 3 & A & 1.50 \\
\hline
\end{tabular}

The setting environment is indicated by a classification number: 1 for inside the observation site of the local meteorological office; 2 for inside the grounds of a local district/commune/police office; 3 for inside the garden of a private house; 4 for on a roof over a private house; and 5 for inside a paddy field. The measuring resolution is $0.5,0.2$, and $1.0 \mathrm{~mm}$ for gauge types $\mathrm{A}, \mathrm{B}$, and $\mathrm{C}$, respectively. The gauge height is from the ground surface to the top of the receiving orifice. Five stations with the symbol "-" are excluded from the analysis due to frequent missing data

More than one missing point per hour resulted in that hour being regarded as a "data-missing hour," and more than one missing hour per day resulted in that day being regarded as a "data-missing day." At each station, a year with more than 10 missing days was regarded as a "data-missing year." Five stations were found to have more than four data-missing years and were thus excluded from our analysis. These stations are indicated by white circles in Fig. 2 and by the symbol "-" in Table 1. With this procedure, we have set severe criteria for the purpose of analyzing rainfall characteristics with only high-quality data.

At stations where both type- $\mathrm{A}$ and type- $\mathrm{B}$ rain gauges are available, we compared the observed rainfall 
amounts from both gauges. The comparison periods are from 1 January 2010 to 31 December 2015 (2191 days) for S4 and from 1 January 2010 to 29 July 2012 (921 days) for M3. The bias (type A minus type B) in hourly rainfall amount averaged throughout the comparison periods is $0.0346 \mathrm{~mm}$ for $\mathrm{S} 4$ and $0.0344 \mathrm{~mm}$ for M3. The mean rainfall amounts in hours when both types of gauges record rainfall equal to or more than $1.0 \mathrm{~mm}$ (the threshold to discuss rainfall frequency in the following sections) are 3.8 and $3.3 \mathrm{~mm}$ in S4 for type $\mathrm{A}$ and type B, respectively, and 3.5 and $2.9 \mathrm{~mm}$ in $\mathrm{M} 3$ for type $A$ and type $B$, respectively. The frequency of rainfall equal to or more than $1.0 \mathrm{~mm} \mathrm{~h}^{-1}$ recorded by both rain gauges is $1.7 \%$, whereas that recorded only by type A is $0.77 \%$ and only by type B is $0.14 \%$ in S4. In $\mathrm{M} 3$, the value is $2.3,0.89$, and $0.27 \%$, respectively. Although there exist some differences and type- $\mathrm{A}$ rain gauges tend to record larger and frequent rainfall than type-B gauges, both types of gauges are used in the following analysis without any bias correction applied. At S4 and M3, we used type-A gauges.

\section{Ground weather data}

Meteorological data observed at the AWS at S7 (see Table 1 and Fig. 2) were used as a reference for local circulation. Among the observed elements, here, we used data on wind direction and wind speed at a $10 \mathrm{~m}$ height, air temperature and relative humidity at a $7 \mathrm{~m}$ height, and air pressure at a $1.5 \mathrm{~m}$ height, in addition to the rainfall amount. The meteorological elements except for rainfall were observed with a $1 \mathrm{~s}$ sampling interval, and we used the preceding $10 \mathrm{~min}$ means as hourly data. In this paper, air humidity is discussed in terms of specific humidity, which is calculated from relative humidity, air temperature, and air pressure.

\section{Global reanalysis data}

The Japanese 55-year Reanalysis data (JRA-55) with a horizontal resolution of $1.25^{\circ}$ and 37 pressure levels were used to check the synoptic-scale atmospheric fields during the target period. Further details of the JRA-55 data are provided by Kobayashi et al. (2015) and Harada et al. (2016).

\section{Analysis}

To aid the description of the results, we divided the surrounding area of the Tonle Sap Lake through the long axis of the lake, which runs from the northwest to the southeast. The rain gauges on the northeastern side of the lake are designated beginning with the letter N. For the southwestern side of the lake, we divided the rain gauges into three further groups: the lakeshore plain and the lower hillslope (stations beginning with the letter S), in the Cardamom Mountains (M), and on the coast facing the Gulf of Thailand (C). The number of rain-gauge stations for the region $\mathrm{N}, \mathrm{S}, \mathrm{M}$, and $\mathrm{C}$ is 7 , 14,6 , and 1 , respectively.

The target period for data analysis is from 1 January 2010 to 31 December 2015.

\section{Results}

\section{Synoptic-scale atmospheric condition}

Figure 3 shows the 6-year-averaged monthly mean synoptic-scale atmospheric fields at $1000 \mathrm{hPa}$ according to JRA-55 data. The 6-hourly data in each month are used to calculate the averages. From March to April (Fig. 3a, b), the monthly mean wind is easterly over the South China Sea and southeasterly over the Gulf of Thailand. From May to September (Fig. 3c, d, e), the entire Cambodia is subject to a large-scale southwesterly wind. From October to November (Fig. 3f, g), the northeasterly wind prevails over the Gulf of Tonkin and the northern South China Sea. From December to February (Fig. 3h, i), the large-scale northeasterly wind becomes stronger with the intrusion of drier air. Thus, in a simple definition on a monthly basis, the summer monsoon season is from May to September, with the pre-monsoon season in March and April and the post-monsoon season in October and November. The dry season is December, January, and February.

\section{Annual and seasonal rainfall}

Figure 4 shows the annual rainfall observed at each rain gauge in inland Cambodia from 2010 to 2015, where "data-missing years" have been excluded. The number of available stations, $N$, and the station-averaged annual rainfall amount are shown for each year. In each bar chart, the rainfall amount from May to September (summer monsoon season) is shown in blue, that from March to April (pre-monsoon season) is in orange, that from October to November (post-monsoon season) is in green, and that in January, February, and December (dry season) is in purple. At the one coastal station in $\mathrm{C} 1$, the annual rainfall amount is obtained only in 2011 and it is $3923 \mathrm{~mm}$, with $2825 \mathrm{~mm}$ in May-September and $551 \mathrm{~mm}$ in OctoberNovember.

The rainfall amount is distinctively large on the southwestern coast facing the Gulf of Thailand (C1) with values of nearly $4000 \mathrm{~mm}$. Except for this station, i.e., over inland Cambodia, the station-averaged annual rainfall ranges from 1087 in 2015 to $1528 \mathrm{~mm}$ in 2011. The difference is $441 \mathrm{~mm}$, corresponding to $33 \%$ of the 6-year average.

The 6-year-averaged rainfall at stations in inland Cambodia shows that the rainfall amount from May to September (summer monsoon season) is $877 \mathrm{~mm}$ on average and varies from 519 to $1350 \mathrm{~mm}$. It is larger in the northern region (N5, N6; around Preah Vihear and Kampong Thom provinces or the Stung Sen River basin) 


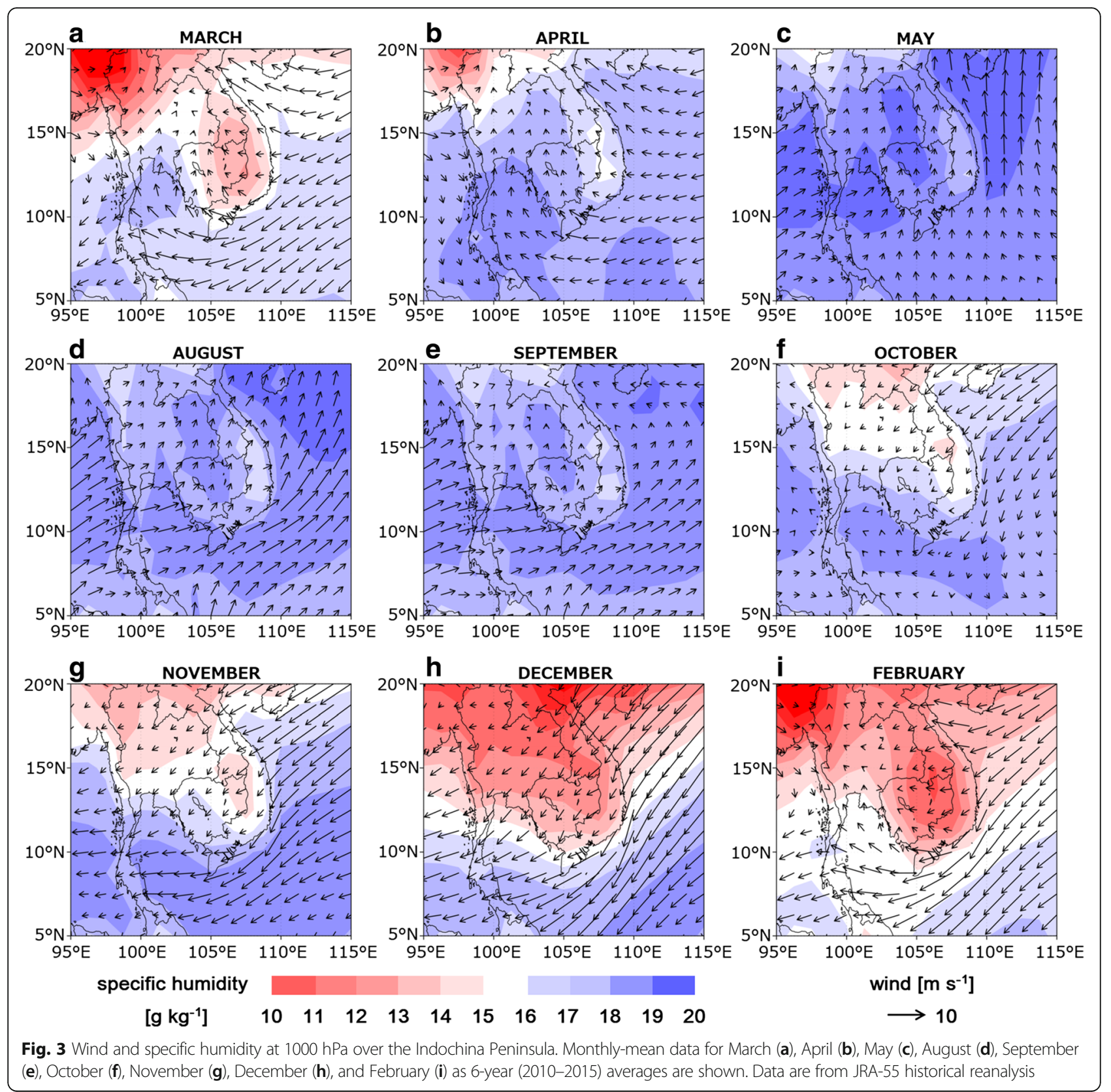

at around 1230-1350 $\mathrm{mm}$ and smaller in the western region (S3, M2, S5, N1, S1; around Battambang province or the Stung Sangkae River basin) at around 520$700 \mathrm{~mm}$. Its proportion to the annual rainfall is $50-78 \%$, with a high proportion mostly in the northern region (N6, N2, N5, N3, S12, N7, and N4 in descending order) and a low proportion in the western region (S5, M2, M1, S3, S4, M4, and M5 in ascending order).

The rainfall amount from March to April (pre-monsoon season) is $137 \mathrm{~mm}$ on average and varies from 63 to $278 \mathrm{~mm}$. It contributes about $5-20 \%$ of the annual rainfall, with a high proportion in the Cardamom Mountains (M4, S3, M3, and M2 in descending order; near the Thai border) and a low proportion mostly in the southern area (N2, S6, S12, and S14 in ascending order; around Pursat and Kampong Chhnang provinces).

The rainfall amount from October to November (post-monsoon season) is $299 \mathrm{~mm}$ on average and varies from 181 to $457 \mathrm{~mm}$. It is larger around the northern ridges of the Cardamom Mountains and the western lakeshore plain (S5, S6, M6, S7, M5, S2, S14, S11, S9, $\mathrm{M} 2$, and M3 in descending order; around Pursat province) and smaller at the northern side of the lake (N3, N6, and N2 in ascending order; around Kampong Thom, Siem Reap, and Oddar Meanchey provinces). It consists 

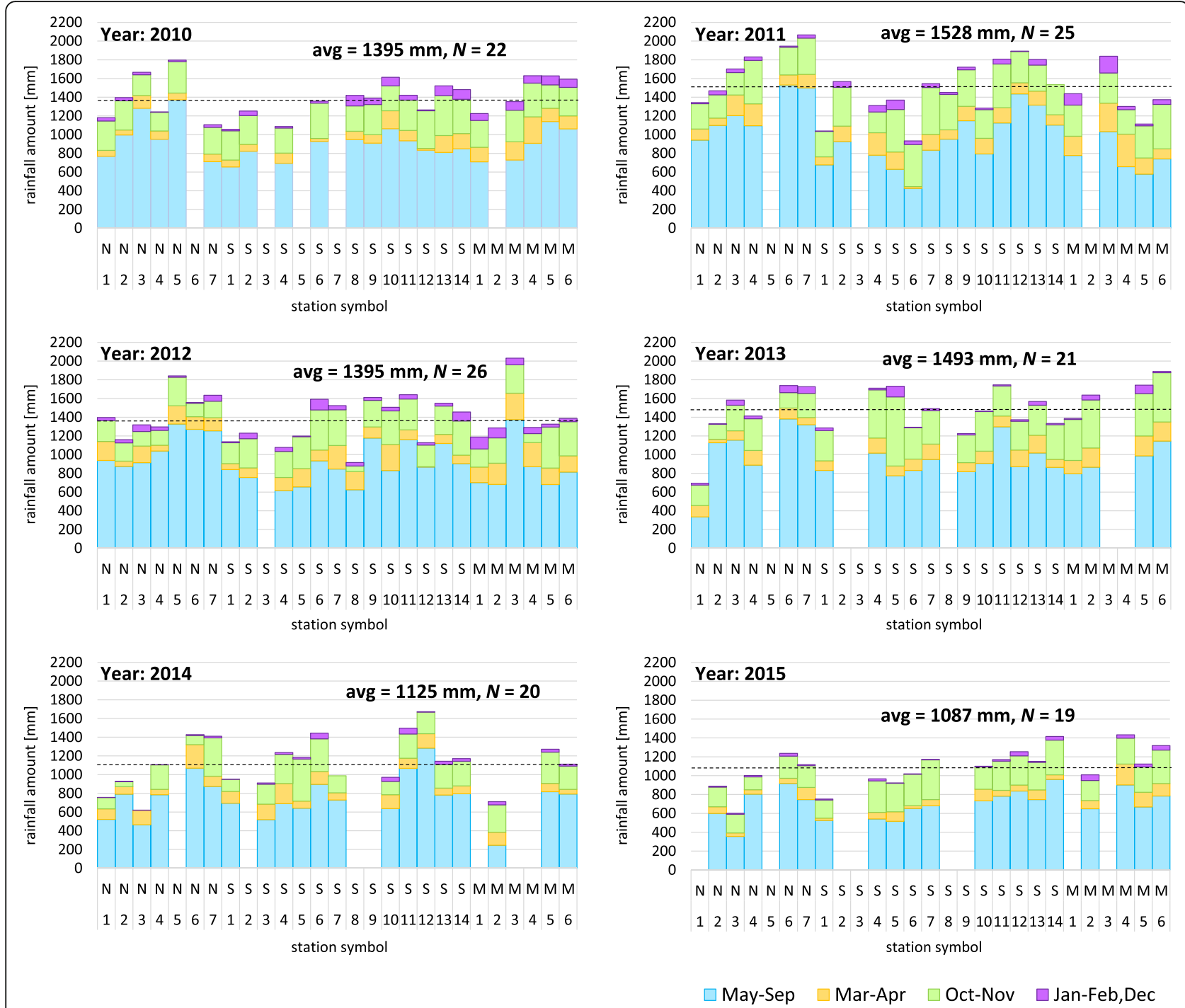

Fig. 4 Annual rainfall observed at each rain gauge in inland Cambodia from 2010 to 2015. Rainfall amounts from May to September (summer monsoon season, in blue), in March and April (pre-monsoon season, in orange), in October and November (post-monsoon season, in green), and in January, February, and December (dry season, in purple) are shown. The station symbol of each station is shown on the horizontal axis. Data in "data-missing years" have been excluded, and the number of available rain gauges, $N$, and annual rainfall amount averaged over available inland rain gauges (except for station (1) are shown in each panel with a broken black line

of $12-36 \%$ of the annual rainfall, with a high proportion at the wide area of the western lakeshore plain in the lower hillslopes of the Cardamom Mountains (S5, S6, M2, S7, M6, S4, S2, and M5 in descending order; around Battambang and Pursat provinces) and a low proportion at the northern side of the lake (N6, N3, N2, M4, and N5 in ascending order; around Kampong Thom, Preah Vihear, Siem Reap, and Oddar Meanchey provinces).

Although an altitudinal increase in the rainy season rainfall has been reported in northern Thailand (Kuraji et al. 2001), the terrain around the Tonle Sap Lake is flat with a mild mountain slope (Fig. 2), and 23 out of 28 gauges used in this analysis are located at the area with an altitude lower than $100 \mathrm{~m}$ (Table 1). The highest station, M4, is located at a $237 \mathrm{~m}$ altitude. The altitudinal difference of gauges is much smaller than in the study by Kuraji et al. (2001), in which the rain gauges were distributed at various altitudes at $282-2535 \mathrm{~m}$. Thus, we consider that the effect of the altitudinal increase in rainfall is not large, if any, in the rainfall observed in this study.

\section{Diurnal cycle of rainfall}

The diurnal cycle of rainfall is discussed mainly in terms of the rainfall frequency by defining any hour with rainfall amount equal to or more than $1.0 \mathrm{~mm}$ as "rainy." At each hour of the day, we calculated the percentage of the number of "rainy" stations against the total number 
of stations for each region, N, S, M, and C, and calculated its season-averaged value for the pre-monsoon, summer monsoon, and post-monsoon seasons. In addition to the rainfall frequency, the rainfall amount is calculated as the station-averaged rainfall amount at each hour. The rainfall intensity is calculated by dividing the rainfall amount by the rainfall frequency. These values are shown in Fig. 5.

For these calculations, we defined these three seasons not on a monthly basis but more exactly by defining the onset and withdrawal dates of the ASM for each year. Among various studies on the definition of the ASM onset, we followed the definition used by Kiguchi and Matsumoto (2005), which considers the onset date to be the day when zonal winds at both 850 and $700 \mathrm{hPa}$ become positive and last for at least 20 days. Similarly, the withdrawal date was defined in this study as the day when zonal winds at both levels become negative and last for at least 20 days. These dates are shown in Table 2 for each year from 2011 to 2015. We then set the pre-monsoon season from 1 March to the previous day of the ASM onset, the summer monsoon season from the onset date to the withdrawal date, and the post-monsoon season from the next day of the withdrawal to 30 November.

We further calculated their 6-year averages for each season for each region to show the averaged diurnal cycle with its seasonal and regional characteristics (Fig. 5). To discuss the spatial variability within region S, Fig. 6 shows the diurnal cycle of the rainfall frequency at each station,

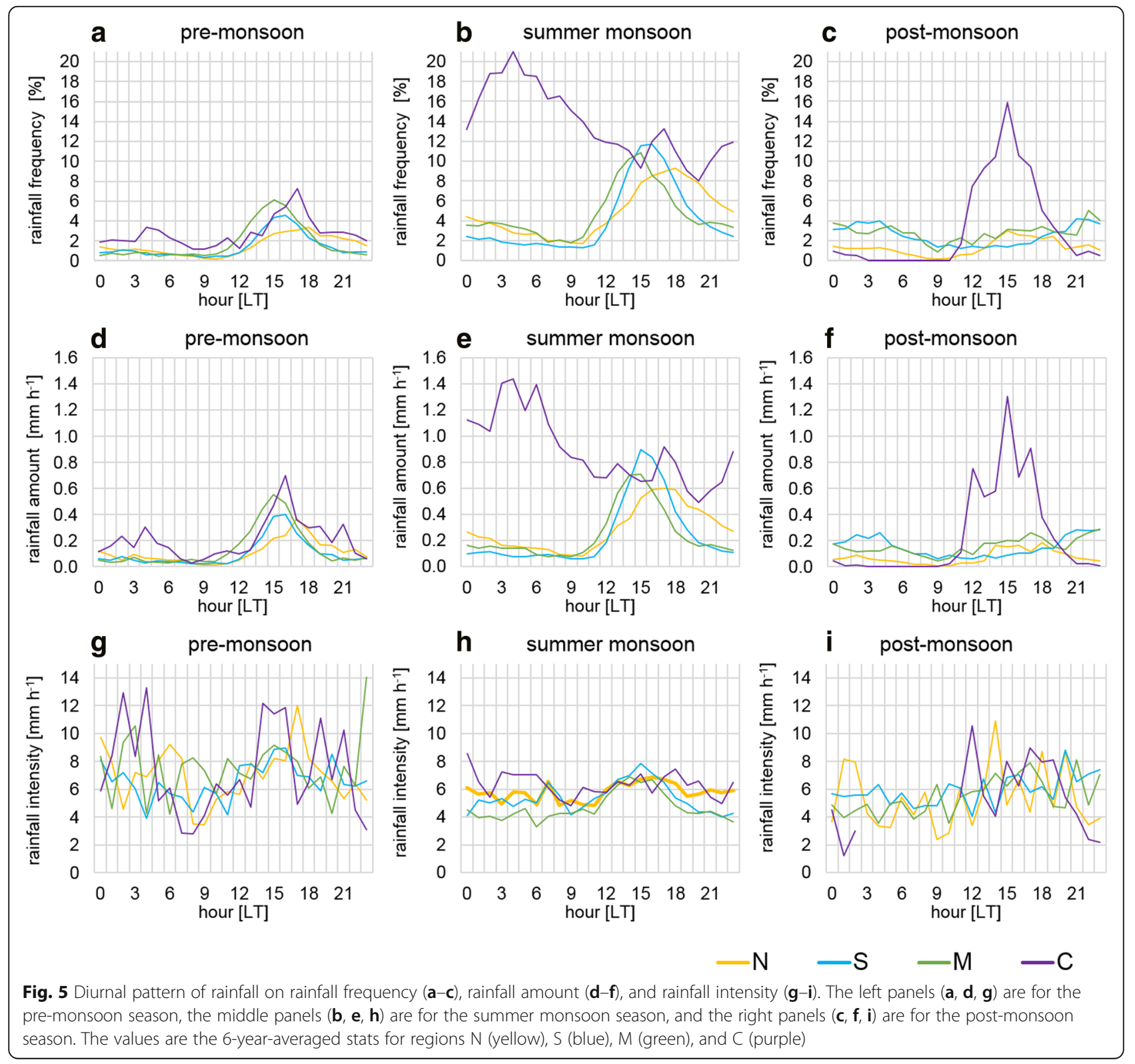


Table 2 Onset and withdrawal dates of the ASM defined for each year in 2010-2015

\begin{tabular}{lllllll}
\hline Year & 2010 & 2011 & 2012 & 2013 & 2014 & 2015 \\
\hline Onset & 22 May & 3 June & 3 June & 7 June & 4 June & 17 June \\
Withdrawal & 13 November & 17 October & 8 October & 29 October & 12 October & 26 October
\end{tabular}

S1 (over the lake), S9 (lower floodplain), S10 (upper floodplain), and S14 (away from the mountain hillslopes).

During the pre-monsoon season, rainfall is frequent in the afternoon over all the four regions (Fig. 5a). The peak frequency is clear at around 15:00-16:00 LT in region $\mathrm{S}$ and 15:00 LT in region $\mathrm{M}$. Region $\mathrm{C}$ has the first peak at 17:00 LT and the second weaker peak at 04:00 LT. The rainfall frequency in region $\mathrm{N}$ is high in the late afternoon with a peak at 18:00 LT. The rainfall intensity is around $4-12 \mathrm{~mm} \mathrm{~h}^{-1}$ (Fig. $5 \mathrm{~g}$ ), showing higher values than other seasons (Figs. 5h, i). The rainfall intensity is especially high in the early morning in region $\mathrm{C}$ and in the afternoon in regions $\mathrm{C}$ and $\mathrm{N}$.

In the summer monsoon season, more than half of the rainfall over the coastal region $\mathrm{C}$ occurs in the early morning, whereas most of the rainfall over inland Cambodia (regions N, S, M) occurs in the afternoon (Fig. 5e). In terms of rainfall frequency, a clear afternoon peak at around 15:00-16:00 LT in region $\mathrm{S}$ and a slightly earlier peak at around 14:00-15:00 LT in region $M$ are observed (Fig. 5b). Among the stations in region S, the peak frequency is lower and less clear over the lake (S1) compared with the inland stations (S9, S10, S14) (Fig. 6). The diurnal patterns over the mountain hillslopes (S9,

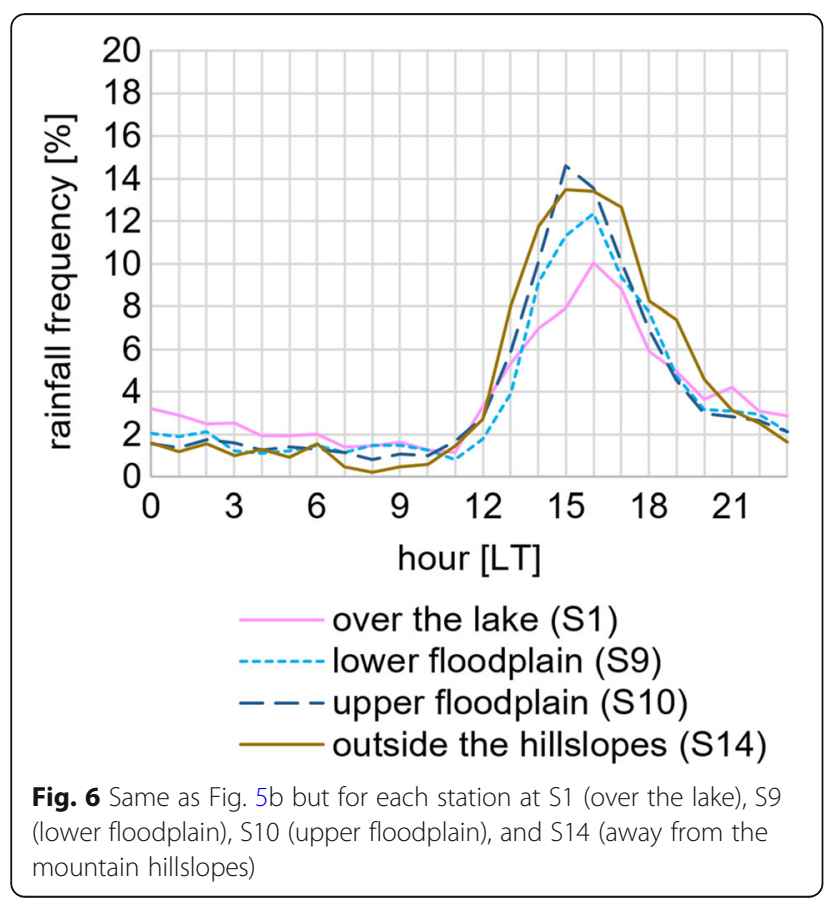

S10) and at the station away from the mountain hillslopes (S14) are similar in Fig. 6, suggesting that the rainfall in region $\mathrm{S}$ are mostly independent systems from those in mountains in region $\mathrm{M}$. In region $\mathrm{N}$, the rainfall frequency has a peak during evening around 18:00 LT. In region $C$, rainfall is frequent at night with a maximum frequency in the early morning at 04:00 LT. The clear regional characteristics of the rainfall pattern within Cambodia imply that, even during the summer monsoon season, most of the rainfall in Cambodia is not simply determined by the strength of the ASM but is highly controlled by local features.

During the post-monsoon season, the peak of the rainfall frequency is in the afternoon at 15:00 LT in regions $\mathrm{N}$ and $\mathrm{C}$ while it is from night to early morning (around 21:00-4:00 LT) in regions $M$ and $S$ (Fig. 5c). More than half of the post-monsoon rainfall occurs at night in region $\mathrm{S}$, and there exist two diurnal peaks of the rainfall amount in the afternoon and at midnight in region $M$ (Fig. 5f). Since the post-monsoon rainfall in regions $M$ and $\mathrm{S}$ is larger than that in region $\mathrm{N}$ as described in the previous subsection, this suggests that the regions which receive relatively large post-monsoon rainfall have the favorable condition for nocturnal rainfall.

\section{Intra-seasonal variability of the diurnal rainfall cycle}

In addition to the season-averaged diurnal rainfall cycle (Fig. 5), the intra-seasonal or day-to-day variability of the clarity of the diurnal rainfall cycle is examined associated with the synoptic-scale atmospheric condition. Since the intra-seasonal variability becomes unclear in multi-year averages, two example years, 2011 and 2015, are selected from the results presented in Fig. 5 to draw the date-hour cross-section for the rainfall frequency, shown in Figs. 7 and 8, respectively. In these figures, the areal-averaged geopotential height at $850 \mathrm{hPa}(\Phi)$ and zonal winds $(u)$ at 850 and $700 \mathrm{hPa}$ from JRA-55 over Cambodia $\left(102-108^{\circ} \mathrm{E}\right.$ and $\left.10-15^{\circ} \mathrm{N}\right)$ at 7:00 LT $(0: 00$ UTC) are shown in each day as indicators of the synoptic-scale atmospheric condition. The peak-frequency hours recognized in Fig. 5 in each region and season are shown with vertical yellow shades. In contrast, the days with prominent rainfall with an ambiguous diurnal cycle or in different hours are shown with horizontal orange broken lines. The horizontal red lines are drawn on 1 March, the onset and withdrawal dates of the ASM shown in Table 2, and 30 November. 


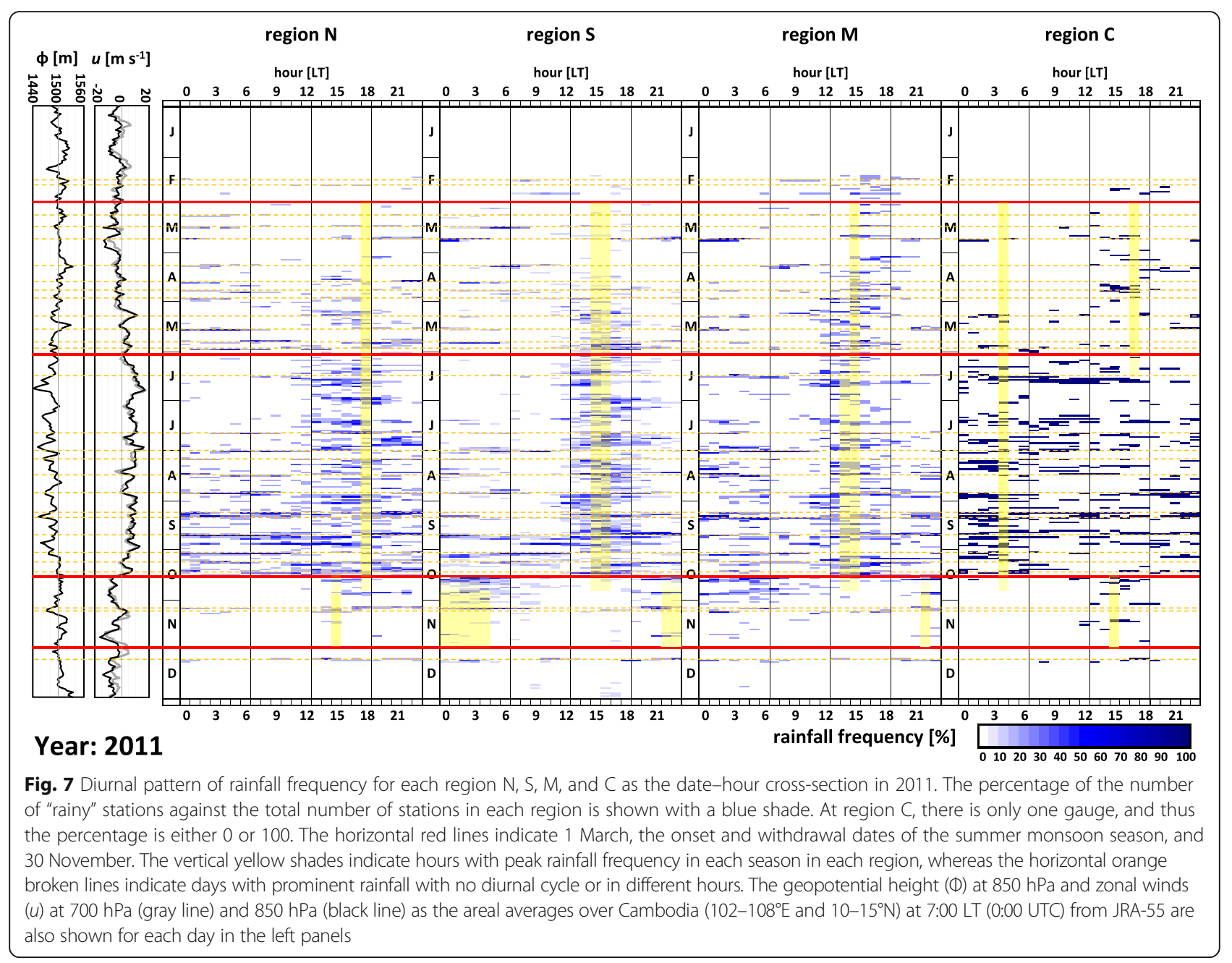

The basic diurnal patterns described in the previous subsection are recognized in both years. However, in 2011, the summer monsoon rainfall in regions $\mathrm{N}$ and $\mathrm{M}$ is frequent in the morning especially during the latter period (Fig. 7), in addition to the characteristic afternoon rainfall recognized in the season-averaged values (Fig. 5b, e). The geopotential height at $850 \mathrm{hPa}$ is low throughout the summer monsoon season in this year, and its depressions often correspond to the broken orange lines in Fig. 7, which show the days without or with different diurnal patterns of rainfall. On the contrary, summer monsoon rainfall is dominant only in the afternoon in most of the days in 2015 (Fig. 8) when the entire Cambodia is mostly covered by high pressure, with a few days having morning rainfall in regions $\mathrm{N}$ and $\mathrm{M}$ corresponding to low pressure.

In the early post-monsoon season, the alteration of rainy hours in region $\mathrm{S}$ from afternoon to midnight is suggested in the season-averaged discussion in the previous subsection, and it is clear in 2011 along with the withdrawal of the ASM. However, the characteristic midnight to early morning rainfall there is not obvious in 2015 when Cambodia is under high pressure.

In summary, the diurnal pattern of rainfall shown in the previous subsection does not always appear, both with days having rainfall in other hours of a day and with days having no rainfall at the expected hours, and it likely occurs under the influence of the synoptic atmospheric condition.

\section{Diurnal cycle of wind direction by ground observation}

The diurnal patterns of wind direction and specific humidity observed at the AWS are shown in Fig. 9 as 6-year-averaged values for April (pre-monsoon season), August (summer monsoon season), and October (post-monsoon season), to examine possible mechanisms underlying the observed diurnal patterns of rainfall as seasonal averages from the viewpoint of local circulation.

In April (Fig. 9a), the wind direction shows a clear diurnal cycle, with northeasterly to easterly wind during the daytime and southwesterly wind during the 


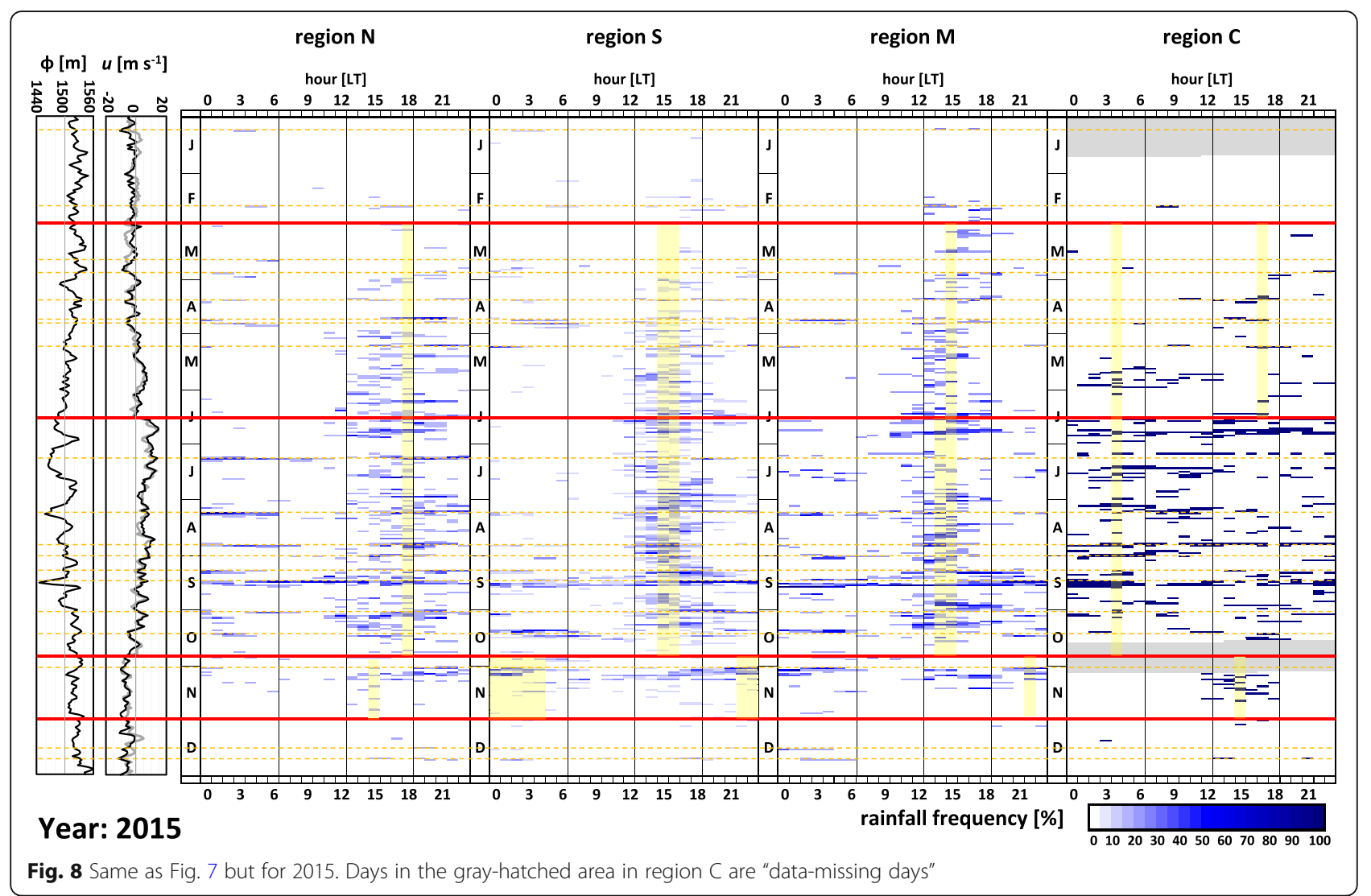

nighttime. Since the lake is located northeast to the AWS, the observed winds at the AWS would be the land-lake breezes resulting from the presence of the Tonle Sap Lake. The alteration from land breeze to lake breeze occurs at about 7:00 LT and from lake breeze to land breeze at around 17:00-19:00 LT. During the daytime lake breeze hours, the specific humidity decreases.

In August (Fig. 9b), the observed wind is northwesterly with 1.4-1.6 $\mathrm{m} \mathrm{s}^{-1}$ during the daytime and southerly to southwesterly during the nighttime. By considering the daytime vector balance with the large-scale wind in JRA-55 data $\left(2.3 \mathrm{~m} \mathrm{~s}^{-1}\right.$ from the southwest at $1000 \mathrm{hPa}$ at the nearest point), the existence of the local atmospheric driving force at about $2.1 \mathrm{~m} \mathrm{~s}^{-1}$ blowing from the direction at $12^{\circ}$ (northerly with a slight easterly component) is suggested to change the wind direction at the local scale. Thus, we can reasonably infer the existence and the effect of the lake breeze originating from the Tonle Sap Lake during the daytime at this location.

In October (Fig. 9c), a clear diurnal cycle of the wind direction is detected at the AWS, with a southwesterly land breeze during the nighttime and a northeasterly lake breeze during the daytime. The alteration between land breeze and lake breeze in wind direction is clearer than in April and occurs at 09:00 and 18:00 LT.

\section{Discussion}

Rainfall amount and its regional difference

The gauge-observed rainfall amount during the summer monsoon season $(877 \mathrm{~mm}$ on average in inland Cambodia) and its spatial distribution coincide with the results by Takahashi et al. (2010a), which showed that summer monsoon rainfall was smaller around the Tonle Sap Lake (less than $760 \mathrm{~mm}$ in 5 months) and slightly larger at the northeastern side of the lake. Under the prevailing ASM, the western region is on the leeward side of the Cardamom Mountains, and the northeastern region is on the windward side of the Annam Range. The gauge-observed spatial distribution of the rainfall in inland Cambodia thus matches the satellite-observed results by Takahashi et al. (2010a), which showed larger rainfall on the leeward side and smaller rainfall on the windward side of mountain ranges.

Further study would be required to analyze the effect of the lake/land breeze circulation in addition to the abovementioned topographical effect for making an observed difference of rainfall amount between regions $\mathrm{N}$ and $\mathrm{S}$. 

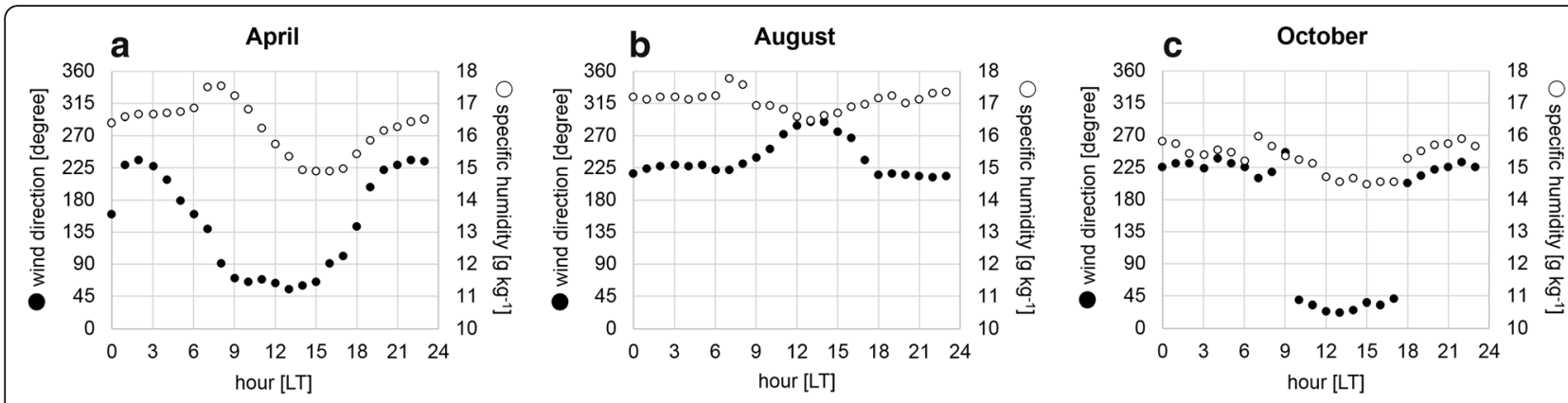

Fig. 9 Diurnal patterns of wind direction (filled circles) and specific humidity (open circles) observed at the AWS at S7 (Fig. 2) in April (a), August (b), and October (c) as 6-year monthly averages

\section{Contribution of pre- and post-monsoon rainfall}

Our ground observation shows that around $22-50 \%$ of annual rainfall in inland Cambodia is brought from January to April and from October to December, i.e., not in the months under the prevailing ASM. This result corresponds with Matsumoto's (1997) study, which suggests the substantial rainfall in April and October. The result also suggests the existence of factors other than the ASM to influence the rainfall in Cambodia.

\section{Intra-seasonal variability and synoptic-scale influences}

Kiguchi and Matsumoto (2005) and Kiguchi et al. (2016) showed that the passage of the synoptic-scale eastward-moving trough produced the intermittent rainfall in Thailand during the pre-monsoon season. Yokoi et al. (2007) showed the predominance of intra-seasonal variations in rainfall over the Indochina Peninsula during the summer monsoon season. Takahashi and Yasunari (2006) and Takahashi et al. (2015) showed that the active and break phases of rainfall in Thailand during the summer monsoon season were brought by the westward propagation of precipitation systems from the western North Pacific. For the post-monsoon season, Nguyen-Thi et al. (2012) showed that approximately $20 \%$ of the rainfall in the central Vietnam coastal area was brought by tropical cyclones, and Chen et al. (2012) showed that the heavy rainfall in Vietnam was basically by the westward-moving disturbances and not due to the northeasterly monsoon itself. Takahashi (2013) investigated clouds and rainfall over the Indochina Peninsula in the post-monsoon season and showed that their characteristics changed within this season, with well-developed cloud-precipitation systems and large rainfall during October and November and low clouds with little rainfall in December, January, and February. He discussed that the first half of the AWM period was probably associated with tropical cyclone activity, although diurnal variation in cloud activity was still recognized, and the low clouds in the latter half would be associated with the orographically forced upward motions.
These previous studies showed that there exist synoptic-scale to intra-seasonal variations for rainfall phenomena over the Indochina Peninsula. Our results in Figs. 7 and 8 show the characteristic diurnal patterns in each region and season as well as the intra-seasonal variations, including days with no clear or different diurnal patterns. Since days with prominent rainfall in different hours correspond to days with lower geopotential height and/or stronger zonal wind, the large-scale low-pressure system and/or disturbances are considered to affect rainfall in Cambodia, as suggested by previous studies.

In this study, the frequently observed typical diurnal patterns of rainfall for each season and region are highlighted for further discussion.

\section{Season-averaged diurnal pattern of rainfall in this region}

Ohsawa et al. (2001) showed that the late night to early morning maximum over tropical Asia from June to August was found at stations with large rainfall amounts. Takahashi et al. (2010b) showed that heavy rainfall in the early morning was found around the coasts over the eastern Gulf of Thailand and the Bay of Bengal, comprising nearly half of the total rainfall there. In our observation, station $\mathrm{C} 1$ located onshore to the western Gulf of Thailand recorded distinctively larger summer monsoon rainfall than other stations in inland Cambodia (Fig. 4), and more than half of the rainfall occurred in the early morning (Fig. 5e). There is no significant difference in the rainfall intensity over regions (Fig. 5h), and large summer monsoon rainfall in the coastal region $C$ is mostly by the higher rainfall frequency there. The late night to early morning rainfall is also dominant in regions $\mathrm{S}$ and $\mathrm{M}$ during the post-monsoon season, where the total rainfall amount is larger. The rainfall intensity is not significantly larger in these regions than in other regions.

In this observation, the diurnal rainfall peak in the summer monsoon season shifts from region $C$ (at 04:00 LT) to regions $M(14: 00-15: 00 \mathrm{LT}), \mathrm{S}(15: 00-16: 00 \mathrm{LT})$, 
and $\mathrm{N}$ (18:00 LT), whereas that in the post-monsoon season shifts from regions $\mathrm{N}$ and $\mathrm{C}(15: 00 \mathrm{LT})$ to regions $M$ and S (21:00-04:00 LT). For northern Thailand, Okumura et al. (2003) showed that the phase shift of the diurnal rainfall cycle moved leeward from mountains corresponding to the wind direction of the prevailing monsoon. The abovementioned observed phase shift in this study agrees with their study considering the southwesterly flow in the summer monsoon season and the northeasterly flow in the post-monsoon season. However, the observed diurnal rainfall peak in the pre-monsoon season moves from regions $M(15: 00 \mathrm{LT})$ and $S$ (15:00-16:00 LT) through region $C$ (17:00 and 04:00 LT) to region $\mathrm{N}(18: 00 \mathrm{LT})$, and this phase shift cannot be explained in relation to the distance to mountains and the prevailing large-scale southeasterly flow.

Although Takahashi (2016) showed by satellite data that precipitation ended in the evening in April and May and lasted until early morning from July to September over the Indochina Peninsula, such characteristics have been recognized only at coastal station $\mathrm{C} 1$. Most of the rainfall in inland Cambodia is observed to occur in the afternoon in both the pre-monsoon and the summer monsoon seasons, except for the dominant evening rainfall in the summer monsoon season in region $\mathrm{N}$.

\section{Local circulation}

The observed diurnal cycle of rainfall can be partly explained by the convergence of the large-scale and local-scale flows, as discussed by Houze et al. (1981). Although further study with numerical simulations is needed to examine the mechanisms of the diurnal rainfall cycle in this region, here we summarize a working hypothesis inferred from data from our dense gauge observations, focusing on the viewpoint from the effect of the land-lake circulation and the low-level wind convergence.

During the pre-monsoon season, the low-level large-scale wind over Cambodia is southerly with a slight easterly component (Fig. 3b). During the daytime at station C1, both the sea breeze from the Gulf of Thailand and the anabatic wind to the Cardamom Mountains are southwesterly, so that no clear low-level winds converging to a large-scale southerly are expected. In this situation, the orographic lifting of moist air from the sea caused by the Cardamom Mountains may determine the observed afternoon rainfall. As pointed out by Xie et al. (2006) regarding the abundant rainfall under the ASM over the Indochina Peninsula, moist air is forced to rise over the mountains and thereby initiate intense convection on the windward side of the orographic lifting. The increased atmospheric instability by sensible heat from the drier ground in this season and also by the low-level intrusion of moist air from the sea contributes to the afternoon rainfall maxima and the abundant rainfall on the coast and over the Cardamom Mountains.

During the summer monsoon season, dominant evening rainfall in region $\mathrm{N}$ characterizes the difference from afternoon rainfall in regions $\mathrm{M}$ and $\mathrm{S}$. Contrary to the southwestern side of the lake, at the northeastern side of the lake (in region N), no clear low-level convergence is expected between the prevailing southwesterly and the daytime lake breeze. Instead, nighttime land breeze converges with the ASM at the northeastern side. Although detection of the land breeze from the AWS data is difficult in August when the land breeze there is expected to flow from almost the same direction with the prevailing ASM, the alteration to land breeze in April is around 17:00-19:00 LT in Fig. 9a and matches the timing of the rainfall peak observed in region $\mathrm{N}$. Therefore, we speculate that the evening rainfall in region $\mathrm{N}$ would be driven by the low-level wind convergence with the ASM at the onset of the land breeze.

The possible mechanism for the afternoon rainfall in regions $\mathrm{M}$ and $\mathrm{S}$ would be the daytime convergence of the southwesterly ASM and the northeasterly lake breeze at the southwestern side of the lake as well as the increased atmospheric instability by sensible heat from the ground. The convergence with the anabatic wind as well as the orographic lifting of the moist lake air over the northeastern slopes of the Cardamom Mountains would also contribute to the afternoon rainfall in region $\mathrm{M}$. On the coast in region C, the ASM converges with the nocturnal northeasterly land breeze and the katabatic wind from the southwestern slope of the Cardamom Mountains, and this would contribute to the late night to early morning rainfall there.

Xie et al. (2006) suggested separate convection lines for dominant rainfall at the southwestern coast in Cambodia, on the coast at the foothills of the Cardamom Mountains, and on the western slope of the Annam Range. However, for our target area west of the Mekong River, the Annam Range is about $400 \mathrm{~km}$ away, and thus, the nighttime katabatic wind is unable to reach this area by evening when the rainfall maximum is observed. Therefore, the observed peak in the evening may result from an independent rainfall system from that initiated by the Annam Range.

During the post-monsoon season, the low-level large-scale southwesterly wind withdraws almost entirely, and dry air intrudes to the Indochina Peninsula with a northeasterly AWM flow (Fig. 3h). The situation in region $\mathrm{N}$ during the post-monsoon season resembles that in region $\mathrm{S}$ during the summer monsoon season, as the daytime lake breeze (southwesterly) converges with the large-scale northeasterly AWM. However, the post-monsoon rainfall amount in region $\mathrm{N}$ is even smaller than that in region $\mathrm{S}$, suggesting 
the importance of the role of the ASM in transporting abundant moisture from the sea as well as the role of the Cardamom Mountains in initiating rainfall. In fact, even during the post-monsoon season, at the coastal station $(\mathrm{C} 1)$ where the AWM converges with a daytime sea breeze and the anabatic wind to the southwestward slope of the Cardamom Mountains, the rainfall amount is large, with the peak occurring in the afternoon. In addition, over region $\mathrm{S}$, the rainfall amount is larger than in other regions in inland Cambodia and most frequent at night when the land breeze and the katabatic wind from the northeastward slope of the Cardamom Mountains converge with the AWM. As Tsujimoto and Koike (2013) demonstrated, a clear nighttime thermal contrast between the lake and the surrounding lands enhanced by the high lake surface temperature is also important for the strong nighttime land breeze circulation associated with the nocturnal rainfall over the southwestern plain.

\section{Conclusions}

Automatic rain-gauge data in Cambodia from 35 stations, including one AWS, have been collected since September 2009, from which the quality-controlled data of 30 of these stations are used to analyze the rainfall characteristics in Cambodia for the period 2010-2015. The analysis focuses on the regional characteristics of the diurnal patterns of rainfall and the underlying mechanisms with reference to the observed surface meteorological data. Although further examination with atmospheric models is required, our discussion of the observed rainfall characteristics and examination of the potential underlying mechanisms can provide a reference for future studies.

The annual rainfall amount in inland Cambodia is $1087-1528 \mathrm{~mm}$ on station-average and is much larger on the coast at nearly $4000 \mathrm{~mm}$. Over inland Cambodia, approximately $5-20 \%$ of the annual rainfall $(63-278 \mathrm{~mm})$ occurs in March and April (pre-monsoon season), 5078\% (519-1350 mm) occurs from May to September (summer monsoon season), and 12-36\% (181-457 mm) occurs in October and November (post-monsoon season).

During the pre-monsoon season, rainfall is dominant on the coast and over the Cardamom Mountains, with a maximum in the afternoon. Orographic lifting as well as atmospheric instability by larger sensible heat from the drier ground is likely the driving mechanism.

During the summer monsoon season, the rainfall amount and its proportion to the annual rainfall are larger in the northern region (around Kampong Thom, Preah Vihear, and Siem Reap provinces) and smaller in the western region (around Battambang province) in inland Cambodia. The rainfall amount on the coast is distinctively large. Clear regional characteristics in the diurnal precipitation patterns are recognized, and they suggest the significant effects of local features even during the ASM season. The diurnal rainfall maximum occurs (i) in the early afternoon in the Cardamom Mountains, (ii) in the afternoon on the plain at the southwestern side of the Tonle Sap Lake, (iii) in the evening on the wide area at the northeastern side of the lake, and (iv) and in the early morning on the coast. The possible mechanism for each rainfall is (a) daytime low-level convergence of the southwesterly ASM and the northeasterly lake breeze at the southwestern side of the lake as well as increased atmospheric instability by sensible heat from land (for (i) and (ii)), (b) daytime low-level convergence of the ASM with the anabatic wind, as well as orographic lifting of the moist lake air, over the northeastern slopes of the Cardamom Mountains (for (i)), (c) low-level convergence of the ASM with the evening northeasterly land breeze at the northeastern side of the lake (for (iii)), and (d) low-level convergence of the ASM with the nocturnal northeasterly land breeze enhanced by the katabatic wind from the southwestern slope of the Cardamom Mountains at the coastal area (for (iv)).

The rainfall amount during the post-monsoon season is larger on the southwestern side of the lake, i.e., around the northern ridges of the Cardamom Mountains and the western lakeshore plain, compared with the other regions in inland Cambodia, with a diurnal maximum at night and in the early morning. It probably results from the low-level convergence of the northeastern AWM with the southwestern land breeze enhanced by the katabatic wind from the northeastern slope of the Cardamom Mountains. Since the rainfall amount is smaller at the northeastern side of the lake where the AWM converges with the daytime lake breeze, the importance of the role of mountains on rainfall is proposed.

The diurnal pattern of rainfall in each season and in each region is, however, not clear on some days, and analysis of the synoptic-scale atmospheric condition suggests the effect of the large-scale low-pressure system and disturbances on the appearance of the clear diurnal rainfall pattern. Further numerical studies are required to examine the effect of the local circulation and the interaction with the synoptic-scale atmospheric condition.

We have demonstrated the diurnal patterns of rainfall in Cambodia with their distinct regional and seasonal characteristics. Clear regional differences suggest the importance of the effect of local features, especially topography, in the formation and development of rainfall in the pre-monsoon, summer monsoon, and post-monsoon seasons, in addition to the synoptic-scale conditions suggested by many previous studies. The study of local effects on rainfall with consideration of the land-surface 


\section{dynamics may aid flood and drought management in Cambodia.}

\section{Abbreviations}

ASM: Asian summer monsoon; AWM: Asian winter monsoon; AWS: Automatic Weather Station; JRA-55: The Japanese 55-year Reanalysis data; LT: Local Time in Cambodia (UTC + 7 h)

\section{Acknowledgements}

We greatly appreciate the kind support from H.E. Mr. Pich Veasna, H.E. Mr. Long Saravuth, Mr. Mao Hak, Mr. Oum Ryna, Mr. Sreng Sotha, Mr. Khum Vany, Mr. Preap Sameng, Mr. Sok Sokhon, and Mr. Mao Soksan of the Ministry of Water Resources and Meteorology, Cambodia, for facilitation of study in Cambodia. We also thank Prof. Toshio Koike for valuable comments during the 7-year observation. We used digital elevation data from the U.S. Geological Survey and global reanalysis data by the Japan Meteorological Agency. The JRA-55 data are used through the Data Integration and Analysis System (DIAS). We are grateful to the editor Prof. Jun Matsumoto and the anonymous reviewers for their helpful and constructive comments that greatly contributed to improving the manuscript from its earlier version.

\section{Funding}

Parts of this research were supported by the Japan Society for the Promotion of Science (JSPS) KAKENHI Grant Numbers JP25820222 and JP16K06503, and also by the Space Applications for Environment (SAFE) and the Precipitation Measuring Mission (PMM) projects by Japan Aerospace Exploration Agency (JAXA), and by the Data Integration and Analysis System (DIAS) by Ministry of Education, Culture, Sports, Science and Technology (MEXT).

\section{Availability of data and materials}

Please contact the author for data requests.

\section{Authors' contributions}

KUT was the principal investigator leading the installation of the observation instrument, designing data analysis, and discussing on the interaction with local circulation. TO conducted data analysis with KuT. KA and KaT conducted fieldwork in Cambodia together with KuT. MSI led the fieldwork with his Cambodian colleagues and provided local information on both observation status and locally known rainfall characteristics. All authors read and approved the final manuscript.

\section{Competing interests}

The authors declare that they have no competing interests.

\section{Publisher's Note}

Springer Nature remains neutral with regard to jurisdictional claims in published maps and institutional affiliations.

\begin{abstract}
Author details
${ }^{1}$ Graduate School of Environmental and Life Science, Okayama University, 3-1-1 Tsushima-naka, Kita-ku, Okayama 700-8530, Japan. ${ }^{2}$ Independent Consultant, Okayama, Japan. ${ }^{3}$ Center for Research in Isotopes and Environmental Dynamics (CRiED), University of Tsukuba, 1-1-1 Tennodai, Tsukuba, Ibaraki 305-8577, Japan. ${ }^{4}$ International Centre for Water Hazard and Risk Management (ICHARM) of the Public Works Research Institute, 1-6 Minamihara, Tsukuba, Ibaraki 305-8516, Japan. ${ }^{5}$ Department of Meteorology, Ministry of Water Resources and Meteorology, 364 Monivong Boulevard, Chamkarmorn, Phnom Penh, Cambodia.
\end{abstract}

Received: 29 June 2017 Accepted: 24 June 2018 Published online: 07 August 2018

\section{References}

Bhatt BC, Nakamura K (2005) Characteristics of monsoon rainfall around the Himalayas revealed by TRMM precipitation radar. Mon Weather Rev 133:149165. https://doi.org/10.1175/mwr-2846.1

Chaboureau JP, Guichard F, Redelsperger JL, Lafore JP (2004) The role of stability and moisture in the diurnal cycle of convection over land. Q J R Meteorol Soc 130:3105-3117. https://doi.org/10.1256/qj.03.132
Chang C-P, Wang Z, McBride J, Liu C-H (2005) Annual cycle of Southeast Asia-maritime continent rainfall and the asymmetric monsoon transition. J Clim 18:287-301. https://doi.org/10.1175/jcli-3257.1

Chen T-C, Tsay J-D, Yen M-C, Matsumoto J (2012) Interannual variation of the late fall rainfall in central Vietnam. J Clim 25:392-413. https://doi.org/10.1175/jclid-11-00068.1

Chhinh N, Millington A (2015) Drought monitoring for rice production in Cambodia. Climate 3:792-811. https://doi.org/10.3390/cli3040792

Earth Observation Research Center (EORC), Japan Aerospace Exploration Agency (JAXA) (2017) Global Rainfall Map in Near Real Time (GSMaP_NRT) and Gauge-calibrated Rainfall Product (GSMaP_Gauge) data format description. http://sharaku.eorc.jaxa.jp/GSMaP/document/DataFormatDescription.pdf. Accessed 5 Feb 2018

Fujinami H, Nomura S, Yasunari T (2005) Characteristics of diurnal variations in convection and precipitation over the southern Tibetan Plateau during summer. SOLA 1:49-52. https://doi.org/10.2151/sola.2005-014

Harada Y, Kamahori H, Kobayashi C, Endo H, Kobayashi S, Ota Y, Onoda H, Onogi K, Miyaoka K, Takahashi K (2016) The JRA-55 reanalysis: representation of atmospheric circulation and climate variability. J Meteor Soc Japan Ser II 94: 269-302. https://doi.org/10.2151/jmsj.2016-015

Hirose M, Nakamura K (2005) Spatial and diurnal variation of precipitation systems over Asia observed by the TRMM Precipitation Radar. J Geophys Res Atmos 110:D05106. https://doi.org/10.1029/2004JD004815

Houze RA Jr, Geotis SG, Marks FD Jr, West AK (1981) Winter monsoon convection in the vicinity of north Borneo. Part I: structure and time variation of the clouds and precipitation. Mon Weather Rev 109:1595-1614. https://doi.org/ 10.1175/1520-0493(1981)109<1595:WMCITV>2.0.CO;2

Kiguchi M, Matsumoto J (2005) The rainfall phenomena during the pre-monsoon period over the Indochina Peninsula in the GAME-IOP Year, 1998. J Meteor Soc Japan. Ser. II 83:89-106. https://doi.org/10.2151/jmsj.83.89

Kiguchi M, Matsumoto J, Kanae S, Oki T (2016) Pre-monsoon rain and its relationship with monsoon onset over the Indochina Peninsula. Front Earth Sci 4:42. https://doi.org/10.3389/feart.2016.00042

Kobayashi S, Ota Y, Harada Y, Ebita A, Moriya M, Onoda H, Onogi K, Kamahori H, Kobayashi C, Endo H, Miyaoka K, Takahashi K (2015) The JRA-55 reanalysis: general specifications and basic characteristics. J Meteor Soc Japan Ser. II 93: 5-48. https://doi.org/10.2151/jmsj.2015-001

Kuraji K, Punyatrong K, Suzuki M (2001) Altitudinal increase in rainfall in the Mae Chaem watershed. Thailand J Meteor Soc Japan Ser II 79:353-363. https://doi. org/10.2151/jmsj.79.353

Masumoto T, Tsujimoto K, Somura H (2007) Hydro-meteorological observation and analysis of observed data at Tonle Sap Lake and its environs, urban and paddy areas. Technical Report of the National Institute for Rural Engineering 206:219-236 In Japanese with English abstract

Matsumoto J (1997) Seasonal transition of summer rainy season over Indochina and adjacent monsoon region. Adv Atmos Sci 14:231-245. https://doi.org/10. 1007/s00376-997-0022-0

McGloin R, McGowan H, McJannet D (2014) Effects of diurnal, intra-seasonal and seasonal climate variability on the energy balance of a small subtropical reservoir. Int J Climatol 35:2308-2325. https://doi.org/10.1002/joc.4147

National Committee for Disaster Management, United Nations Development Programme (2014) Cambodia disaster loss and damage analysis report 1996-2013. http://www.kh.undp.org/content/cambodia/en/home/library/ environment_energy/cambodia-disaster-loss-and-damage-analysis-report1996-2013.html of subordinate document. Accessed 29 Jun 2017

Nguyen-Thi HA, Matsumoto J, Ngo-Duc T, Endo N (2012) A climatological study of tropical cyclone rainfall in Vietnam. SOLA 8:41-44. https://doi.org/10.2151/ sola.2012-011

Nieuwolt S (1981) The climates of continental Southeast Asia. In: Takahashi K Arakawa $\mathrm{H}$ (eds) Climates of southern and western Asia. World survey of climatology 9. Elsevier, Amsterdam

Ohsawa T, Ueda H, Hayashi T, Watanabe A, Matsumoto J (2001) Diurnal variations of convective activity and rainfall in tropical Asia. J Meteor Soc Japan Ser. ॥ 79:333-352. https://doi.org/10.2151/jmsj.79.333

Okumura K, Satomura T, Oki T, Khantiyanan W (2003) Diurnal variation of precipitation by moving mesoscale systems: radar observations in northern Thailand. Geophys Res Lett 30:2073. https://doi.org/10.1029/2003GL018302

Ono M, Takahashi HG (2016) Seasonal transition of precipitation characteristics associated with land surface conditions in and around Bangladesh. J Geophys Res Atmos 121:11,190-111,200. https://doi.org/10.1002/ 2016JD025218 
Satomura T (2000) Diurnal variation of precipitation over the Indo-China PPeninsula: two-dimensional numerical simulation. J Meteor So Japan Ser II 78:461-475. https://doi.org/10.2151/jmsj1965.78.4_461

Satomura T, Yamamoto K, Sysouphanthavong B, Phonevilay S (2011) Diurnal variation of radar echo area in the middle of Indochina. J Meteor Soc Japan Ser. II 89A:299-305. https://doi.org/10.2151/jmsj.2011-A20

Save Cambodia's Wildlife (2006) The atlas of Cambodia: national poverty and environment maps. Phnom Penh

Singh P, Nakamura K (2009) Diurnal variation in summer precipitation over the central Tibetan Plateau. J Geophys Res Atmos 114:D20107. https://doi.org/10. 1029/2009JD011788

Sugimoto S, Takahashi HG (2017) Seasonal differences in precipitation sensitivity to soil moisture in Bangladesh and surrounding regions. J Clim 30:921-938. https://doi.org/10.1175/jcli-d-15-0800.1

Takahashi HG (2013) Orographic low-level clouds of Southeast Asia during the cold surges of the winter monsoon. Atmos Res 131:22-33. https://doi.org/10. 1016/j.atmosres.2012.07.005

Takahashi HG (2016) Seasonal and diurnal variations in rainfall characteristics over the tropical Asian monsoon region using TRMM-PR data. SOLA 12A:22-27. https://doi.org/10.2151/sola.12A-005

Takahashi HG, Fujinami H, Yasunari T, Matsumoto J (2010a) Diurnal rainfal pattern observed by Tropical Rainfall Measuring Mission Precipitation Radar (TRMM-PR) around the Indochina Peninsula. J Geophys Res Atmos 115: D07109. https://doi.org/10.1029/2009jd012155

Takahashi HG, Fujinami H, Yasunari T, Matsumoto J, Baimoung S (2015) Role of tropical cyclones along the monsoon trough in the 2011 Thai flood and interannual variability. J Clim 28:1465-1476. https://doi.org/10.1175/jcli-d-1400147.1

Takahashi HG, Yasunari T (2006) A climatological monsoon break in rainfall over Indochina-a singularity in the seasonal march of the Asian summer monsoon. J Clim 19:1545-1556. https://doi.org/10.1175/jcli3724.1

Takahashi HG, Yoshikane T, Hara M, Takata K, Yasunari T (2010b) High-resolution modelling of the potential impact of land surface conditions on regional climate over Indochina associated with the diurnal precipitation cycle. Int J Climatol 30:2004-2020. https://doi.org/10.1002/joc.2119

Torti J (2012) Floods in Southeast Asia: a health priority. J Global Health 2:020304. https://doi.org/10.7189/jogh.02.020304

Tsujimoto K, Koike T (2008) Mechanism of locally-induced convection development and its effects on vapor transportation over Tonle Sap Lake area. Ann J Hydraulic Eng Japan Soc Civil Eng 52:247-252. https://doi.org/10. 2208/prohe.52.247 In Japanese with English abstract

Tsujimoto K, Koike T (2012) Requisite conditions for post-monsoon rainfall in Cambodia by looking through 2009 rainfall data. J Hydrosci Hydraul Eng 30:1-14

Tsujimoto K, Koike T (2013) Land-lake breezes at low latitudes: the case of Tonle Sap Lake in Cambodia. J Geophys Res Atmos 118:6970-6980. https://doi.org/ 10.1002/jgrd.50547

Tsujimoto K, Masumoto T, Mitsuno T (2008) Seasonal changes in radiation and evaporation implied from the diurnal distribution of rainfall in the Lower Mekong. Hydrol Process 22:1257-1266. https://doi.org/10.1002/hyp.6935

Verburg P, Antenucci JP (2010) Persistent unstable atmospheric boundary layer enhances sensible and latent heat loss in a tropical great lake: Lake Tanganyika. J Geophys Res Atmos 115:D11109. https://doi.org/10.1029/ 2009JD012839

Wallace JM (1975) Diurnal variations in precipitation and thunderstorm frequency over the conterminous United States. Mon Weather Rev 103:406-419. https://doi.org/10.1175/1520-0493(1975)103<0406:dvipat>2.0.co;2

Xie S-P, Xu H, Saji NH, Wang Y, Liu WT (2006) Role of narrow mountains in largescale organization of Asian Monsoon convection. J Clim 19:3420-3429. https://doi.org/10.1175/jcli3777.1

Yen M-C, Chen T-C, Hu H-L, Tzeng R-Y, Dinh DT, Nguyen TTT, Wong CJ (2011) Interannual variation of the fall rainfall in Central Vietnam. J Meteor Soc Japan Ser II 89A:259-270. https://doi.org/10.2151/jmsj.2011-A16

Yokoi S, Satomura T, Matsumoto J (2007) Climatological characteristics of the intraseasonal variation of precipitation over the Indochina Peninsula. J Clim 20:5301-5315. https://doi.org/10.1175/2007jcli1357.1

Yu R, Zhou T, Xiong A, Zhu Y, Li J (2007) Diurnal variations of summer precipitation over contiguous China. Geophys Res Lett 34:L01704. https://doi. org/10.1029/2006GL028129

Zhang Y, Li T, Wang B, Wu G (2002) Onset of the summer monsoon over the Indochina Peninsula: climatology and interannual variations. J Clim 15:3206-3221. https://doi.org/10.1175/1520-0442(2002)015<3206:00tsmo>2.0.c0;2

\section{Submit your manuscript to a SpringerOpen ${ }^{\circ}$ journal and benefit from:}

- Convenient online submission

- Rigorous peer review

- Open access: articles freely available online

- High visibility within the field

- Retaining the copyright to your article

Submit your next manuscript at $\boldsymbol{\nabla}$ springeropen.com 